JIKAP PGSD: Jurnal Ilmiah Ilmu Kependidikan

Vol,3. No,3. Tahun 2019

e-ISSN: 2597-4440 dan p-ISSN: 2597-4424

This work is licensed under a Creative Commons Attribution

4.0 International License

\title{
Pengaruh Model Pembelajaran Treffinger Terhadap Hasil Belajar Matematika Siswa SD Negeri 37 Model Parepare
}

\author{
Zaid Zainal' $^{1}$, Abdul Halik ${ }^{2}$, Madania ${ }^{3}$ \\ ${ }^{123}$ PGSD Fakultas Ilmu Pendidikan Universitas Negeri Makassar \\ Email: ${ }^{1}$ zaid.zainal@unm.ac.id \\ 2abdul.halik@unm.ac.id \\ 3madaniaachmad@gmail.com
}

\begin{abstract}
Abstrak. Penelitian ini menelaah tentang uji coba model pembelajaran treffinger pada mata pelajaran matematika siswa SD Negeri 37 Model Parepare. Penelitian ini bertujuan untuk mengetahui apakah terdapat pengaruh model pembelajaran treffinger terhadap hasil belajar matematika siswa SD Negeri 37 Model Parepare. Penelitian ini menggunakan pendekatan kuantitatif dengan jenis penelitian eksperimen dan menggunakan desain Quasy Experimental dalam bentuk The Nonequivalent Pre-test Post-test Control Group Design. Teknik sampling yang digunakan dalam penelitian ini adalah purposive sampling dengan jumlah sampel yaitu 67 siswa. Teknik pengumpulan data yang digunakan dalam penelitian ini adalah observasi, tes dalam bentuk pilihan ganda, dan dokumentasi. Analisis data menggunakan teknik statistik deskriptif dan statistik inferensial. Hasil pengujian hipotesis menggunakan uji Paired Sample T-Test diperoleh signifikansi $0,00(0,00<0,05)$ dan hasil analisis dari uji t diperoleh nilai $-\mathrm{t}_{\text {hitung }}<-\mathrm{t}_{\text {tabel }}(-17,999<-2,037)$ menunjukkan bahwa $\mathrm{H}_{0}$ ditolak yang artinya terdapat perbedaan rata-rata hasil belajar matematika siswa SD Negeri 37 Model Parepare antara sebelum dan sesudah penggunaan model pembelajaran treffinger. Berdasarkan hasil tersebut maka dapat disimpulkan bahwa model pembelajaran treffinger berpengaruh terhadap hasil belajar matematika siswa SD Negeri 37 Model Parepare.
\end{abstract}

Kata kunci: Model pembelajaran Treffinger, hasil belajar matematika

Abstract.. This study examines the trial of treffinger learning models on mathematics
subjects in elementary school students of SD 37 Model Parepare. The aim of this
study was to find out whether there is an influence of Treffinger learning model on
mathematics learning outcomes of students of SD Negeri 37 Model Parepare. This
study uses a quantitative approach to the type of experimental research and uses the
Quasy Experimental design in the form of The Nonequivalent Pre-test Post-test
Control Group Design. The sampling technique used in this study was purposive
sampling with a sample of 67 students. Data collection techniques used in this study
were observation, tests in the form of multiple choices, and documentation. Data
analysis uses descriptive statistical techniques and inferential statistics. The results of
hypothesis testing using the Paired Sample T-Test test obtained significance of 0.00
(0.00 <0.05) and the results of the analysis of the t test obtained values - tcount <- $t$
table $(-17.999<-2.037)$ indicate that $\mathrm{H}_{0}$ is rejected which means there are differences
in the average mathematics learning outcomes of elementary school students 37 Model
Parepare between before and after the use of the Treffinger learning model. Based on 
these results, it can be concluded that the Treffinger learning model influences the mathematics learning outcomes of students of SD Negeri 37 Model Parepare.

Keywords: Treffinger learning model, mathematics learning outcomes

\section{PENDAHULUAN}

Keberhasilan dalam kemajuan suatu negara tergantung pada kondisi pendidikan di negara tersebut. Semakin berkembang pendidikan disuatu negara, maka semakin maju dan berkembang negara tersebut. Setiap negara menyadari bahwa pembangunan dibidang pendidikan sangat perlu menjadi perhatian utama. Salah satunya Indonesia merupakan negara berkembang yang sedang membangun.

Pemerintah Indonesia selalu berusaha meningkatkan kualitas pendidikannya. Salah satu usahanya melalui pengembangan kurikulum. Seperti halnya saat ini, kurikulum KTSP dikembangkan menjadi kurikulum 2013. Kurikulum mempunyai peranan penting yang diantaranya menuntun proses pembelajaran menjadi terarah.

Kurikulum 2013 adalah salah satu upaya yang dapat dilakukan untuk menciptakan pendidikan yang lebih maju dengan mencetak siswa yang berkompeten, inovatif dan kreatif sehingga diharapkan mampu menghadapi tantangan di masa mendatang. Pada kurikulum 2013, terdapat salah satu mata pelajaran yang terpisah dari tematik, yaitu Matematika. Hal ini dikarenakan pada kurikulum 2013 sebelum revisi, kedalaman materi buku tematik terpadu terasa dangkal, sehingga guru mengajarkan materi secara tidak mendalam dan siswa pun tidak mendapatkan pemahaman konsep matematika secara mendalam. Melihat kondisi tersebut pemerintah merevisi mata pelajaran matematika dengan mengeluarkan Peraturan Menteri Pendidikan dan Kebudayaan (Permendikbud) Nomor 24 Tahun 2016 pasal 1 ayat 3 tentang kompetensi inti (KI) dan kompetensi dasar (KD) pelajaran pada kurikulum 2013 pada pendidikan dasar dan pendidikan menengah menyatakan bahwa pelaksanaan pembelajaran pada Sekolah Dasar/Madrasah Ibtidaiyah (SD/MI) dilakukan dengan pendekatan pembelajaran tematikterpadu, kecuali untuk mata pelajaran Matematika dan Pendidikan Jasmani Olahraga dan Kesehatan (PJOK) sebagai mata pelajaran yang berdiri sendiri untuk kelas IV, V, dan VI.

Dalam peningkatan kualitas pendidikan, matematika merupakan salah satu mata pelajaran pada jenjang pendidikan yang memegang peran penting. Hal ini dibuktikan dengan melihat bahwa pelajaran matematika diberikan kepada semua tingkat pendidikan mulai dari sekolah dasar, sekolah menengah sampai perguruan tinggi.

Pembelajaran harus efektif dalam mencapai tujuan pembelajaran. Tujuan dari pembelajaran yaitu untuk mengubah tingkah laku yang diperoleh melalui pengalaman. Untuk itu, pembelajaran yang berlangsung memerlukan perencanaan yang matang, media yang bervariasi serta sarana dan prasarana yang memadai. Pembelajaran yang efektif dapat tercapai apabila dalam prosesnya ditunjang oleh beberapa faktor penting antara lain melalui penggunaan model pembelajaran yang tepat. Dalam hal ini, Lestari (2017 : 219) mengemukakan bahwa penggunaan model pembelajaran yang tepat dapat mendorong tumbuhnya rasa senang siswa terhadap pelajaran, menumbuhkan dan meningkatkan keaktifan siswa, dan memberikan kemudahan bagi siswa untuk memahami pelajaran sehingga memungkinkan siswa mencapai hasil belajar yang lebih baik.

Dengan demikian, model pembelajaran sangat penting untuk meningkatkan motivasi dan semangat siswa dalam belajar sehingga dapat memfasilitasi siswa untuk memperoleh hasil belajar yang diharapkan. Berdasarkan hasil Olimpiade Sains Nasional (OSN) Matematika tingkat SD Kecamatan Bacukiki Kota Parepare tahun 2019 nilai rata-rata yang capai siswa yaitu 14,25.Angka tersebut menunjukkan bahwa tingkat pencapaian matematikanya masih rendah. Untuk memperoleh hasil belajar yang sesuai dengan yang diharapkan maka diperlukan model pembelajaran yang tidak hanya memberi pengetahuan kepada siswa tetapi mampu merangsang daya berpikir siswa. Salah satu model pembelajaran yang tepat digunakan yaitu model pembelajaran treffinger.

Model pembelajaran treffinger merupakan model pembelajaran yang mencakup dua ranah, yaitu kognitif dan afektif. Model treffinger terdiri dari 3 tahap, yaitu tahap pertama basic tools, tahap ini meliputi keterampilan berpikir divergen dan teknik-teknik 
kreatif. Keterampilan dan teknik-teknik ini mengembangkan kelancaran dan kelenturan berpikir serta kesediaan mengungkapkan pemikiran kreatif kepada orang lain. Tahap kedua practice with process, pada tahap ini siswa diberi kesempatan untuk menerapkan keterampilan yang dipelajari pada tingkat basic tools dalam situasi praktis. Tahap ketiga working with real problems, pada tingkat ini siswa menerapankan keterampilan yang dipelajari pada tingkat basic tools dan practice process terhadap dunia nyata.

Berdasarkan hasil observasi yang telah dilakukan pada tanggal 18 Maret 2019 di SD Negeri 37 Model Parepare, pada saat pembelajaran berlangsung siswa pada umumnya mempelajari matematika hanya diberi tahu oleh gurunya dan bukan melaui kegiatan eksplorasi. Hal tersebut mengakibatkan siswa kurang kreatif dalam memecahkan masalah yang berkaitan dengan matematika. Selain itu, guru belum pernah menerapkan model pembelajaran lain.

Berdasarkan kenyataan di atas, maka peneliti bermaksud untuk menguji model pembelajaran treffinger terhadap hasil belajar matematika siswa SD Negeri 37 Model Parepare. Penelitian ini bertujuan untuk mengetahui apakah terdapat pengaruh model pembelajaran treffinger terhadap hasil belajar matematika siswa kelas V SD Negeri 37 Model Parepare.

\section{METODE PENELITIAN}

Penelitian ini adalah penelitian eksperimen yang menggunakan pendekatan kuantitatif. Jenis penelitian ini dipilih karena peneliti berusaha melakukan uji coba dengan memberikantindakan (treatment) berupa model pembelajaran treffinger untuk mengetahui pengaruh yang ditimbulkan terhadap pencapaian hasil belajar matematika siswa SD Negeri 37 Model Parepare.

Penelitian ini menggunakan desain eksperimen semu atau biasa disebut quasy eksperimen. Menurut (Sugiyono, 2015) desain penelitian eksperimen semu mempunyai kelompok kontrol, tetapi tidak dapat berfungsi sepenuhnya untuk mengontrol variabel-variabel luar yang mempengaruhi pelaksanaan eksperimen.Adapun bentuk desain quasy eksperiment yang digunakan dalam penelitian ini yaitu the nonequivalent pre-test post-test design. Dalam penelitian ini, sebelum melakukan penelitan kedua kelompok diberi tes atau disebut juga pre-test. Setelah itu kelompok pertama diberikan perlakuan dan kelompok yang lain tidak diberi perlakuan. Kelompok yang diberi perlakuan dijadikan kelompok eksperimen dan kelompok yang tidak diberi perlakuan dijadikan kelompok kontrol. Selanjutnya kedua kelompok diberikan post-test untuk membandingkan apakah terdapat perubahan atau tidak. Adapun desain penelitian ini dapat digambarkan sebagai berikut:

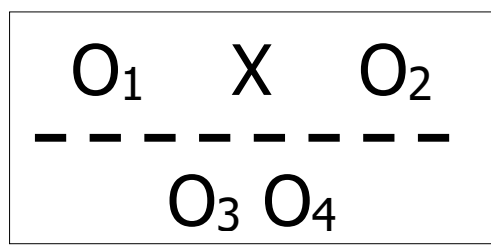

Sumber: diadaptasi oleh Lestari dan Yudhanegara (2015)

Gambar 3.1 Desain Penelitian The

Nonequivalent pre-test post-test design

Keterangan :

$\mathrm{O}_{1} \quad$ : Pre-test kelas eksperimen

$\mathrm{O}_{2} \quad$ : Post-test kelas eksperimen

$\mathrm{X}$ : Perlakuan (treatment) yang diberikan, yaitu model pembelajaran treffinger

$\mathrm{O}_{3}$ : Pre-test kelas kontrol

$\mathrm{O}_{4}$ : Post-test kelas kontrol

Variabel dalam penelitian terdiri dari dua jenis, yaitu variabel bebas dan variabel terkontrol. Variabel bebas adalah model pembelajaran treffinger, sedangkan variabel terkontrolnya adalah hasil belajar matematika siswa SD Negeri 37 Model Parepare. Populasi dalam penelitian ini adalah seluruh siswa SD Negeri 37 Model Parepare dengam jumlah 409 siswa dan jumlah kelas 15 rombel. Teknik pengambilan sampel yang digunakan yaitu purposive sampling. Menurut Sugiyono (2015:124) "purposive samping adalah teknik penentuan sampel dengan pertimbangan tertentu". Peneliti memilih kelas V sebagai sampel karena model pembelajaran yang digunakan hanya cocok untuk kelas tinggi. Jumlah sampel dalam penelitian ini sebanyak 67 orang siswa.

Adapun teknik pengumpulan data yang digunakan dalam penelitian ini adalah sebagai berikut:

1. Observasi

Teknik pengumpulan data dengan observasi digunakan untuk mengamati aktivitas belajar siswa dan kegiatan mengajar guru sebagai objek penelitian. 


\section{Tes}

Tes yang digunakan dalam penelitian ini adalah tes tertulis dalam bentuk pilihan ganda sebanyak 20 nomor pada pre-test dan post-test. Soal tes dibuat berdasarkan indikator yang akan dicapai, kemudian divalidsi logis yaitu validasi isi (konten).

3. Dokumentasi

Data penunjang dalam penelitian ini berupa dokumentasi yang meliputi daftar nama siswa kelas V baik laki-laki maupun perempuan, standar ketuntasan belajar minimal (SKBM) mata pelajaran matematika, jadwal mata pelajaran matematika, gambar dan video saat proses pembelajaran sedang berlangsung.

Teknik analisis data yang digunakan dalam penelitian ini yakni analisis statistik deskriptif dan analisis statistik interferensial. Analisis deskriptif dalam penelitian ini digunakan untuk mendeskripsikan hasil belajar matematika siswa ketika diberi perlakuan berupa penggunaan model pembelajran treffinger dengan data deskriptif berupa tabel distribusi dari min, max, mean, median, modus, dan standar deviasi. Adapun analisis statistik inferensial yang digunakan dalam penelitian ini adalah sebagai berikut:

a. Pengujian Persyaratan Data

Syarat yang harus dipenuhi sebelum melakukan pengujian terhadap hipotesis adalah melakukan pengujian normalitas dan homogenitas. Seluruh perhitungannya dilakukan dengan menggunakan bantuan komputer program Statistical Package for Social Sciences (SPSS) Versi 22.

1) Uji Normalitas

Berdasarkan hasil analisis uji normalitas dengan menggunakan SPSS versi 22 diperoleh nilai signifikansi $\rho=0,072>\alpha=0.05$ pada pre-test dan $\rho=0,074>\alpha=0.05$ pada post-test. Maka dapat disimpulkan bahwa data berdistribusi normal.

2) Uji Homogenitas

Berdasarkan hasil pengujian homogenitas dengan menggunakan SPSS versi 22diperoleh nilai signifikansi $\rho=0,150>\alpha=$ 0.05 . maka dapat disimpulkan bahwa varian data pre-test dan post-test sampel dinyatakan homogen.

b. Uji Hipotesis

Uji hipotesis digunakan untuk menganalisis data yang telah diperoleh dari hasil pre-test dan post-test. Data dianalisis dengan menggunakan rumus uji Paired Sample T-Test.

\section{HASIL DAN PEMBAHASAN}

Berdasarkan penelitian yang telah dilakukan pada siswa kelas VA (kelas eksperimen) dan kelas VB (kelas kontrol) di SD Negeri 37 Model Parepare melalui penggunaan model pembelajaran treffinger terhadap hasil belajar matematika, nilai statsitik deskriptif hasil belajar matematika materi volume kubus dan balok pada kelas eksperimen dan kelas kontrol dapat diihat sebagai berikut:

Tabel 1: Karakteristik nilai statistik deskriptif hasil belajar siswa kelas eksperimen dan kelas kontrol Statistika Nilai Statistika

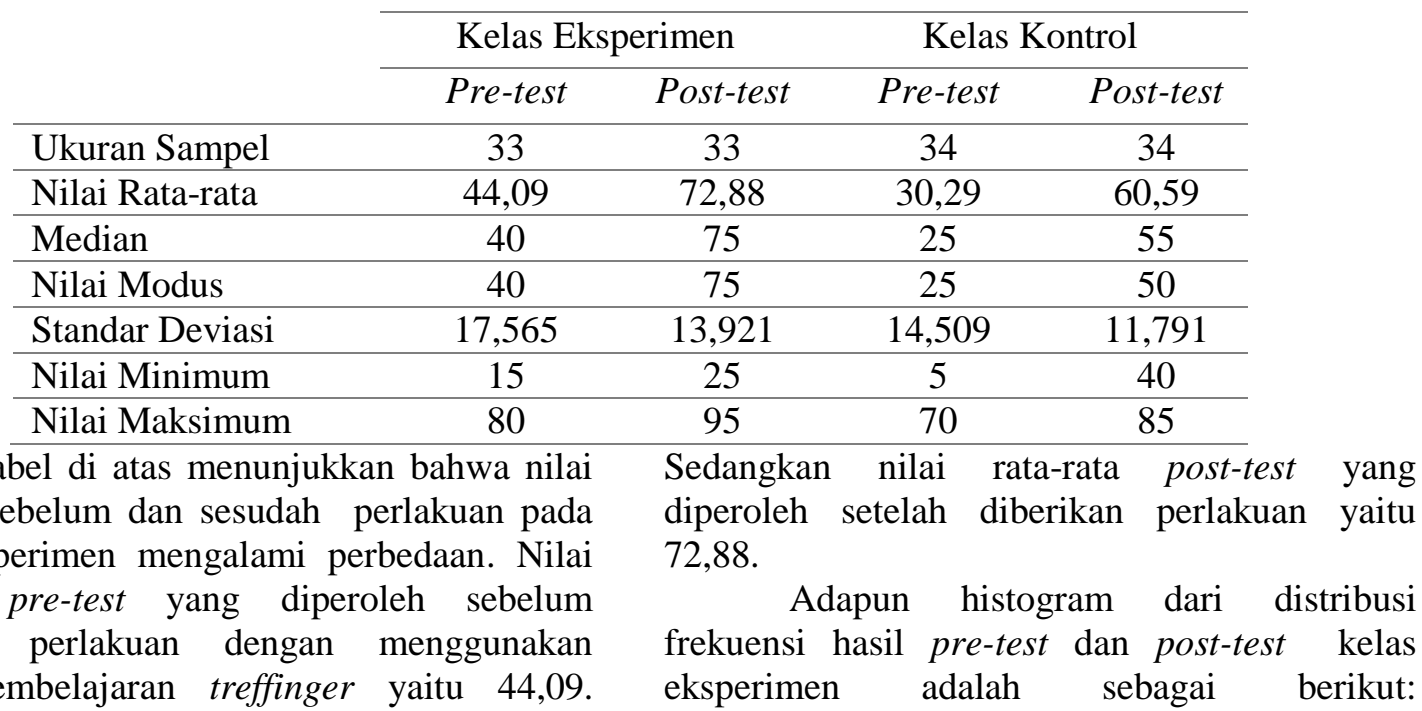


Nilai Rata-rata Pre-test dan Post-test Kelas Eksperimen

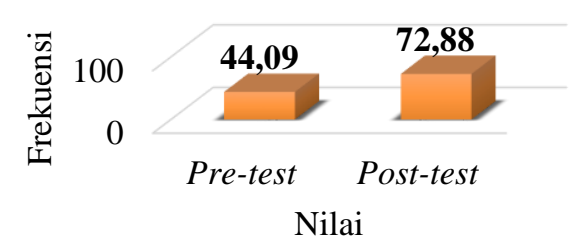

Gambar 1. Diagram Batang Rata-rata Nilai Pre-test dan Post-test Kelas Eksperimen

Hasil pengujian hipotesis menggunakan uji Paired Sample T-Test diperoleh signifikansi $0,00(0,00<0,05)$ dan hasil analisis dari nilai $\mathrm{t}$ diperoleh nilai $-\mathrm{t}_{\text {hitung }}<-\mathrm{t}_{\text {tabel }}(-17,999<-$ 2,037)menunjukkan bahwa $\mathrm{H}_{0}$ ditolak dan $\mathrm{H}_{\mathrm{a}}$ diterima yang artinya terdapat perbedaan ratarata hasil belajar matematika siswa SD Negeri 37 Model Parepare antara sebelum dan sesudah penggunaan model pembelajaran treffinger.

\section{SIMPULAN DAN SARAN}

Berdasarkan rumusan masalah, hasil penelitian dan pembahasan diperoleh bahwa, terdapat perbedaan rata-rata nilai pre-test dan post-test penggunaan model pembelajaran treffinger terhadap hasil belajar matematika siswa SD Negeri 37 Model Parepare. Hal itu ditunjukkan dengan signifikansi $0,00(0,00<$ $0,05)$ dan nilai $-t_{\text {hitung }}<-t_{\text {tabel }}(-17,999<-2,037)$ dengan demikian $\mathrm{H}_{0}$ ditolak.Hasil uji hipotesis ini menunjukkan bahwa terdapat pengaruh positif yang signifikan penggunaan model pembelajaran treffinger terhadap hasil belajar matematika siswa SD Negeri 37 Model Parepare, dengan kata lain model pembelajaran treffinger berpengaruh terhadap hasil belajar matematika siswa SD Negeri 37 Model Parepare.

Berdasarkan kesimpulan diatas, maka peneliti mengajukan beberapa saran dari hasil penelitian untuk pihak-pihak lain, antara lain:

1. Bagi kepala sekolah, model pembelajaran merupakan salah satu komponen penting dalam pembelajaran, salah satunya adalah model pembelajaran treffinger. Maka dari itu, perlu adanya apresiasi yang tinggi bagi guru yang dapat mengembangkan model pembelajaran yang kreatif dan efektif.

2. Bagi guru, diharapkan dapat menggunakan model pembelajaran treffinger dalam mencapai hasil belajar matematika dengan baik.
3. Bagi siswa, agar dapat mengikuti proses pembelajaran dengan lebih aktif, antusias, dan terus menggali pengetahuan terkait materi pembelajaran khususnya mata pelajaran Matematika.

4. Bagi peneliti selanjutnya, diharapkan dapat dijadikan sebagai salah satu referensi dalam melakukan penelitian serta dapat mengembangkan model pembelajaran treffinger dalam memecahkan permasalahan matematika sekolah dasar.

\section{DAFTAR RUJUKAN}

Lestari, K.E. \& Yudhanegara, M.R. 2015. Penelitian Pendidikan Matematika. Bandung: PT Refika Aditama.

Lestari. E. 2017. Upaya Peningkatan Kerja Sama dan Prestasi Belajar dengan Model Pembelajaran Team Assisted Individualized (TAI) dibantu Media LKS pada Materi Stroikiometri Di Kelas X MIPA 1 Semester Genap SMA Negeri 6 Surakarta Tahun Pelajaran 2016/2017. Jurnal Pendidikan Empirisme, ISSN. 2301-5848: 127-135.

Peraturan Menteri Pendidikan dan Kebudayaan Republik Indonesia Nomor 24 Tahun 2016. Kompetensi Inti dan Kompetensi Dasar Pelajaran Pada Kurikulum 2013 Pada Pendidikan Dasar dan Pendidikan Menengah. Jakarta.

Sugiyono. 2015. Metode Penelitian Pendidikan (Pendekatan Kuantitatif, Kualitatif, dan $R \& D)$. Bandung: Alfabeta. 